\title{
PERCEPTIONS OF EXPERIENCED AND NOVICE TEACHERS ABOUT THE IMPORTANCE OF LESSON PLANNING FOR EFFECTIVE LEARNING IN PRIVATE ELEMENTARY SCHOOLS OF GILGIT CITY
}

\author{
Dil Angaiz \\ Assistant Professor, Department of Educational Development \\ Karakoram International University, Gilgit \\ dilangaiz@kiu.edu.pk \\ Zahra Jabeen \\ Lecturer, Department of Educational Development \\ Karakoram International University, Gilgit \\ zahra.jabeen@ku.edu.pk \\ Nazia Karim \\ Lecturer, Department of Educational Development \\ Karakoram International University, Gilgit \\ nazia.karim@kiu.edu.pk
}

\begin{abstract}
This study intended to explore the perceptions of novice and experienced teachers about the importance of lesson planning for effective learning in selected private elementary schools in Gilgit city. A qualitative approach focusing on case study was used to conduct this study. The researchers collected data by using in-depth semi-structured interviews. The study revealed that novice and experienced teachers both realized the importance to lesson planning. It was revealed that lesson planning contributes to students learning. Although teachers use different formats to plan their lessons. Moreover, it was found that novice teachers regularly develop their lessons in detail on the other hand experienced teachers do not regularly plan their lessons in detail. Teachers' workload was one of the hurdles in planning lesson. On the basis of the findings it was recommended that teachers should develop lesson plans for their classes because it provides guideline and teachers can teach effectively which ultimately improves students learning.
\end{abstract}

Keywords: Perceptions, novice teachers, experienced teachers, lesson planning, private schools, Gilgit city

\section{INTRODUCTION}

Every teacher education program spends a large amount of time in teaching novice teachers how to write detailed lesson plans. However, when they enter into real classroom teaching, their responses get diverse. For some novice teachers, lesson planning is a matter of showing their creativity and for others; it is just a source of anxiety. For some, planning lessons is so difficult to learn (John, 2006). Lesson plan is a process in which teachers use different steps to enhance student learning and improve their teaching strategies (Wong, 2009). Similarly, Cicek (2013) claimed that lesson plans ensure the "effective use of class time and classroom management by giving positive experience to students; by administering routines about beginning and ending the class and possible transitions, warm ups for tardy students and extra activities for students which finish class assignments early" (p. 334).

A lesson plan consists of the teachers' working philosophy, knowledge, information about students, understanding of the objectives of education, his experience about the materials to be taught and capacity to use methods to teach effectively (Singh, 2007). Mahon (2011) stated that it is a sequenced outline for a fixed time which tells the teachers how to teach students effectively for the ongoing instructions. Similarly, Sarosdy (2006) reported that lesson plan is a pathway to reach the destination through following the designed aims and objectives. Where the instructor needs to focus the essential components of the lesson plans to deliver the content in planned period. Also he further suggested to the instructors' that they should consider the level of understanding of the learners during the development of the lesson planning. 
Marzano, Marzano, and Pickering (2003) conducted a study over 60,000 students which revealed that the most important factor affecting students' achievement is the teacher. In his famous book Wong (2009) described the characteristics of an effective teacher. He asserted that an effective teacher has positive expectations from students about their success, and his/her lesson plan reflects those expectations. Wong further stated that an effective teacher knows how to plan a lesson for students' learning and how to manage his/her class time and managing classroom which is reflected in his/her lesson plan. In an educational setting according to Asfaw (2002), lesson plans are prior decisions to be made to carry out the instructional processes. The absence of proper lesson plans doesn't guarantee the success of instructional processes (Asfaw, 2002). Many experienced teachers put less effort in preparation of their lessons, however, novice teachers prepare detailed lesson plans especially in the beginning of their teaching career (Romiszoweski, 1984 at cited tin Asfaw, 2002).

Coletta and Norris-Bauer (n.d) claimed that novice teachers are like novice physicians who need to know about good practices in teaching by initially following necessary details and procedures before going to adopt the short cuts. Effective teaching and learning cannot be achieved with short cuts; a detailed planning is needed which is possible by planning lessons (Asfaw, 2002). It is revealed from the literature that lesson planning is an essential component of the classroom teaching. Also development of lesson planning before teaching helped teachers change the traditional class into modern classes. Educational experts and other educational researchers agreed that there is crucial role of lesson planning in the effective teaching and effective learning.

\section{Statement of the Problem}

Despite of the importance of planning lessons in teaching and learning process, research (McCutcheon, 2002) consistently showed that experienced teachers do not develop detailed written lesson plans. Teachers even with few years of teaching experience do not develop lesson plans. McCutcheon further stated that teachers do plan lesson when they reach a new topic for the very first time. He further said that experienced teachers more rely on their mental planning has recurrently proved that Lesson plans help teachers by citing the learning outcomes, motivational activities, time management, and selection of content, methods of teaching method, teaching resources, student assessment, students 'previous knowledge, and homework for students (Ornstein, 1997). Therefore, in ordered to further study it convinced the researchers to conduct a study on the importance of lesson planning and its effect on student learning.

\section{Purpose of the Study}

The main purpose of this study was to explore the perceptions of novice and experienced private school teachers about the importance of lesson planning and its effects on students' learning at elementary level in the context of Gilgit-Baltistan in Gilgit city. Moreover, it also intended to explore different models used by teachers to plan their lessons. Further, it also explored the problems faced by the teachers while designing effective lessons.

\section{Significance of the Study}

This study might be a value addition to the indigenous knowledge related to the context of GilgitBaltistan as there is scare research on lesson planning in Pakistan in particular. Further, this study might be significant for elementary school teachers because lesson planning plays a crucial role in teaching and learning process without planning it is impossible for teachers to deliver their lessons successfully. Moreover, the study might be a proof for novice teachers and teacher education institutions to highlight the importance of lesson plans and to address the challenges faced by teachers while designing lesson plans. Further, future researchers may also explore this topic further based on the findings of this study.

\section{REVIEW OF LITERATURE}

There is a famous saying that planning is half done. Lesson planning is the first step in teaching learning process in which teachers design objectives for their learners, prepare activities, select suitable methods and techniques to teach a particular content and materials needed to teach in a specified time (Afswa, 2002). Similarly, according to Coppola (2004), lesson plan is most important 
Perceptions of Experienced and Novice Teachers about the Importance of lesson planning...

part of learning arrangement and it is heart of teaching. The thought of lesson planning is academic successor idea of Piaget (1976).

Nesari and Heidari (2014) defined lesson plan as "a written description of teaching process in which it is shown what, when, where and which methods students should learn and how they should be assessed" (p.25). Similarly, according to Farrell (2002), lesson plan is a record of teachers' thoughts about what the content need to be covered during a lesson. Farrell further stated that lesson plan describes how students will move towards attaining learning outcomes.

According to Agarwal (1996), good lesson planning is one of the most important elements in teaching. Lesson planning is the mental readiness of teachers to deliver an effective lesson. Agarwal further added that teachers, who go to class unprepared, without having specific objective, activities, and methods in mind, become aimless in delivering a particular content. Aggarwal (1996) asserted that teachers enter the classroom without lesson plans because teachers believe that lesson plans contribute little in guiding teachers' activities in classroom. Romiszoweski (as cited in Agarwal, 1996) claimed that some teachers teach very effectively even without a formal and detailed lesson preparation. On the other hand, there are teachers who do not give effective lesson even with the detailed lesson plans. Agarwal found it controversial because how teachers can give effective lesson without any detailed written lesson plan. Agarwal further added that teachers having a long teaching experiences and with strong content knowledge can decide which methods and teaching materials will be used to teach effectively. It is difficult for teachers to use classroom time wisely and to ensure students understanding of the content until and unless they decide what content will be taught by using which method and materials (Agarwal, 1996).

Due to the complex phenomenon of learning, it is challenging for people to learn all different skills. Many people do not have the required competencies to be self-directed learners. Therefore, lesson plans economize people's limited capacity for learning (Nesari \& Heidari, 2014). According to John (1993), planning is an important movement for teachers as they get engaged in this process for almost 6 hours every week and nearly 17 hours exhausted teaching in classroom. This exhausting process can be eased by planning proper lesson because lesson plans provide directions for teachers to choose method and material suitable to the content taught (Spratt, Pulverness, \& Williams, 2005). If lessons are not planned properly then learning process may be boring for learners. Boredom can be avoided by making proper plans and decisions by teachers (Nesari \& Heidari, 2014).

Reed and Michaud (2010) claimed that the process of lesson planning enables teachers to judge their own knowledge with regard to the content they teach. For instance, a teacher has to teach a particular topic about which he/she is not sure or has less knowledge, so, during lesson planning he/she will acquire the required knowledge. Likewise, Jensen (2001) stated that with a proper lesson plan, teachers feel confident in classroom which ultimately leads to respect gain from students. Through planning, teachers have a clear idea of what to teach, how, and when to teach a particular content. Jensen further added that through proper lesson planning teachers save their time because they already planned every step of the lesson. In this way they will not waste their time looking for activities, flipping textbook or reference books and so on.

Lesson planning according to Calderhead (1984) often undervalued despite of being a vital aspect of classroom teaching. He further added that lesson planning is the only tool which helps teachers to translate syllabus guidelines. Similarly, Clark and Yinger (1987) considered lesson planning as demanding process which is the combination of knowledge and cognitive skills. They further added that through lesson planning, curriculum can be aligned with students' learning. Moreover, it is a set of teachers' expectations with regard to the events in a teaching process which proceed in a specific time period. Davies and Rogers (2000) on the other hand asserted that lesson plan may not be considered as a true guideline to what actually happens in classroom, however, it shows a purpose to teach or to act.

According to Koszalka (1999), many researchers examined how teachers make arrangements for teaching which shows that teaching arrangements play an important part in instruction and creating a successful educational situation. Kizlik (2007) was of the view that teachers have knowledge or the ability of instruction, preparing their content and teaching strategy is basically significant. Similarly, Amininik, Amami, Jalalpour, and Azodi (2000) claimed that one of the ways to promote quality education is proper lesson planning by teachers because it is the foundation of education. Therefore, Coppola, Scricca, and Conners (2004) consider lesson planning as a core of 
education. Through proper lesson preparation, diversity in classroom can be addressed because without lesson planning teachers cannot cater for students with different abilities and characteristics (Beech, 2002). Likewise, Brown (1995) claimed that a systematically planned lesson guarantees better results in teaching.

Lesson planning demands a lot of teachers' professional time. For instance, John (1994) concluded that teachers spent approximately six hours on planning lessons per week whereas teachers spend nearly 17 hours in classroom teaching. This professional time is called as "the hidden world of teaching" by Clark and Yinger (1987). During this professional time, teachers understand the curriculum, develop activities, and act upon it while teaching in classroom (John, 1991).

Practice of planning lessons in different countries is different. For instance, In China, teachers and school community plans lessons in two steps: preparing a lesson plan and refining the plan through open lessons (Shen et al., 2007 a). Koszalka (1999) stated that lesson plans support teachers by documenting particular objectives, motivational introductions, outlines or necessities, assessment strategies, and requirements for learner such as homework. Clark and Peterson (1986) stated that novice teachers develop more detailed lesson plans which helps them to proceed on in a smooth way. On the other hand, experienced teachers develop brief lesson plans because they have more classroom knowledge. Experienced teachers can develop intellectual image of their classroom proceedings. Similarly, Jensen (2001) compared experienced English as Second Language teachers and novice teachers and reported that novice teachers develop more detailed lesson plans for their classroom teaching whereas experienced teachers' developmental plan about what and how they are going to proceed.

Villagran (2014) stated that a lesson plan contains a lot of information about a particular classroom and teaching process. There are lots of components of a lesson plan which need to be considered by teachers while planning. For instance, as Clark and Peterson (1986) reviewed a lot of literature on lesson planning and they concluded that the most commonly used model for planning was rational model introduced by Tylor in 1949. This model described lesson planning process in four steps. According to Tyler (1949), first step was to determining purpose and educational objectives, identifying learning experiences for learners to attain the educational objectives, choosing suitable instructional strategies to achieve the designed educational objectives, and evaluation procedures to see how far educational objectives were achieved.

Contrary to Tyler, Taba (1962) asserted that planning consists of a statement of aims followed by specific objectives, selection and organization of content, and evaluation of specific objectives. On the other hand, according to John (2006), Wise (1976) came up with another idea of instructional planning which was called as planning by objective.

According to Jensen (2001), lesson planning is an opportunity for teachers to think thoroughly about the themes they teach, objectives they set related to those themes, selection of activities to meet the objectives, time required for each activity, and selection of evaluation tools to see whether the objectives have been achieved or not. Moreover, teachers have to see a clear connection among all the elements of a lesson plan.

Lang (1994) stated that there are certain steps to plan lessons. He stated that the initial step is to decide a topic related to a particular instructional part. The next step is to make learning objectives in connection with the topic. Lang further stated that learning objectives or outcomes need to be connected to the abilities of students as well. On the other hand, John (1996) stated that there are several steps to plan a lesson which starting with the selection of the topic in connection with the national curriculum followed by designing objectives, methods to teach the content, and activities to achieve the objectives. Dean (1996) further added that lesson plans can be developed with a revision of students' prior knowledge related to the topic. This step also diagnoses what students will be able to achieve after the lesson. Richard - Amato (2009, p. 39) suggested five major steps to plan a lesson.

1. Opening: develop a clear link of the topic with students' previous knowledge.

2. Simulation: taking lead into the main teaching activity to develop interest in the lesson.

3. Instruction: major content of the lesson is taught.

4. Closure: at the end of the instruction, a review of whatever has been learnt by learners.

5. Follow-up: finally, homework is assigned to do it independently.

There are plenty of components according to Villagran (2014) which a teacher needs to take into account while planning a lesson. For instance, teachers should be aware of the setting or the 
Perceptions of Experienced and Novice Teachers about the Importance of lesson planning...

context of a lesson where they teach. Enerson, Plank, and Johnson (2000 as cited in Villagran (2014) asserted that before going to plan anything, teachers need to reflect on their students, their abilities, their likes and dislikes about the methods of teaching, and what type of activities do they like, individual work or group work and so on.

Nesari and Heidari (2014) carried out a survey research on 93 secondary English language teachers about their views about lesson planning in Iran. The study revealed that most of the teachers develop lesson plans due to its importance and contribution towards quality education. Hannon (2000) reported that teachers considered lesson planning as important and beneficial act. Despite of workload and less knowledge of teachers about lesson planning, still they plan lessons. Similarly, Moradana and Pourasadollah (2014) reported that mostly experiences and older teachers don't plan their lessons neither they preview their lessons prior to their class. Similarly, highly educated teachers do not use lesson plans despite of realizing its importance. On the other hand, new and younger teachers claimed that lesson plans give them confidence to teach students on classroom that's why they regularly plan their lessons. There have been dissenters to this view; some scholars reported that the nature of lesson planning and the kind of information included can vary greatly. Experienced teachers can teach from their mental plans rather than a detailed lesson plan (Richard \& Bohlke, 2011).

\section{RESEARCH DESIGN}

The researchers used qualitative paradigm to explore the perception of novice and experiences teachers about the importance of lesson planning for effective learning in private elementary schools in Gilgit city. Within the qualitative paradigm, the researchers used case study method because the purpose of this study required detailed and in depth understanding about the study area. The researchers purposefully selected a private sector elementary school located in Gilgit city where developing lesson plans was a school policy. Therefore, the teachers were using proper lesson plans for teaching. A total of 450 students enrolled in different grades from class I to 8 . There were 18 teachers and majority of them were female teachers (12 females and 6 males). The researchers conveniently selected four teachers out of eighteen, two novice teachers and two experienced teachers. Both the experienced teachers had 6-8 years of teaching experience in the same school whereas two of the novice teachers had one and half years of teaching experience in the same school. All teachers had a master degree in different disciplines.

Prior to start data collection, an informed consent was shared and signed by the school principal and sample teachers. A semi structured interview was designed to collect data for the study and the researchers conducted 25-30 minutes long interview with the research participants. interviews were audio recorded with the permission of the research participants, transcribed, translated, and analyzed later. The interview questions were prepared in English and interviews were conducted in both English and Urdu language. The rationale behind conducting a bilingual interview was to facilitate research participants so that they could participate, and can freely described their ideas without a language barrier. Ultimately, the researchers could be able to collect authentic and valid information for the study. The data was analyzed against the questions asked and later linked the similar ideas and given a theme.

\section{RESULTS}

\section{i. $\quad$ Elementary teachers' perceptions about lesson planning}

Upon asking about lesson plan and its effectiveness, both experienced and novice teachers highlighted their understanding of lesson plan and its importance for students' learning. The experienced teacher A was of the view that lesson planning is a blue print of a design which depicts the classroom activities in a limited time. She further added that with the help of this guideline, teachers can achieve their lesson objectives easily. Similarly, the experienced teacher B stated that lesson plan is very important tool for her as a teacher because it is like a road map and the teachers and the students achieve their objectives in a specific time and by using of lesson plan teacher can prepare herself for managing the lesson. She further added that "lesson plan gives me confidence to stand in front of the class confidently. It also helps me to manage my time well because while planning, I think through all the possible ways to execute the lesson effectively". Both the experienced teachers were of view of that the effective lesson planning means to achieve, goals and objectives of their lesson in a specific time. It is the lesson planning which actually interprets the syllabus, the overall expectations of the 
school and teachers and put into actions in a doable manner. The experienced teachers further added that by making lesson plans they have improved their planning skills by managing time and content on their own. Moreover, lesson planning also helps them to imagine and create a learning environment in the class because it given opportunities to think about variety of ways to keep students busy in different activities.

Similarly, the novice teacher $\mathrm{C}$ was of the view that "the effective lesson planning means a detailed guideline which I develop for every class I teach by keeping in mind the topic, students previous knowledge, the available teaching aids, and my own teaching methodology". She further added that lesson plan gives her confidence to teach in the classroom. If she goes to the class without lesson plan, she feels lost. She faces the issues of classroom management where she cannot control over students' responses and questions. Likewise, for novice teacher D lesson plan is very important for teachers to teach effectively. She was of the view that "through lesson planning they do not waste their classroom time". Novice teacher D further added that for her lesson planning for a teacher is very similar to a hunter's life. For a hunter he must keep a weapon every time and get success in his task. Similarly, if a teacher makes the lesson plan simply he or she will be able to get success in her/his teaching and achieves his/her objectives. She concluded that "lesson plan is my weapon to teach in an effective manner".

By analyzing the responses of experienced and novice teachers, it is concluded that lesson planning is a guideline; it's a blue print for teachers which depicts the classroom happening before hand. Through lesson planning, novice and experience teachers both achieve their lesson objectives in a specified time. Moreover, it gives them confidence to teach to their classes without any confusion. While planning, teachers think about the overall syllabus, its objectives, their own teaching methodology, students' previous knowledge, and the resources or teaching aids available to them. Lesson plan helps them to organized themselves, manage their class in an effective manner, and keep students busy during class in purposeful activities.

\section{ii. Lesson planning and students' learning}

Upon asking about the effect of lesson planning on students' learning, the experienced teacher A, respond that, "lesson plan is not only important for teachers but for students as well. Although teachers develop lessons for their own comfort and need however, it ultimately affects students' learning in a positive way". She further added that "teachers who plan their lessons by keeping in mind the students' previous knowledge and competencies, they can develop students from that point onwards. In this way students' learning will be better and focused". The experienced teacher A further added that when teachers plan purposeful activities for students, students get an ample opportunity in the classroom to do those activities and become active learners in a specific period of time. The experienced teacher B had the similar ideas. She said that she had been planning lessons over the last seven years which enabled her to make appropriate and relevant decisions about selecting objectives, teaching methods, and activities for students. She claimed that she has learnt all this through her teaching experience.

The novice teacher $\mathrm{C}$ and $\mathrm{D}$ had similar views as they stated that an effective lesson plan is a tool which focuses teacher as well as students on the objectives of the lesson. If the teacher carefully constructs and executes the lesson, it enables the learner to achieve the learning outcomes. Both the participants agreed that there is a positive relationship between student learning and lesson planning. Lesson plan is developed for student learning. They further added that while lesson planning, teachers think about all possible questions student can rise during the class, therefore, teachers think about the answers prior to the class. In this way students get answers and satisfied on the spot. Moreover, lesson plans help in managing classrooms as classroom management is one of the major elements of teaching process and without an effective classroom management no learning can happen. When teachers plan their lessons it ultimately contributes to their student's learning.

Thus, it is concluded that lesson planning is not only important for teachers but it is also important for students' learning. It has positive relationship with students' learning. So the lesson plan should be developed in such a way which should provide the basic information to the teacher and students. It should contain all components of a lesson and provide the subway for student learning. If the teacher can make a lesson the student can learn more things in a specific time. Because though lesson plan, teachers save their time and well manage and organize teaching resources. 
Perceptions of Experienced and Novice Teachers about the Importance of lesson planning...

\section{iii. $\quad$ Models of lesson planning}

Upon asking questions about the models of lesson plan which they follow on daily basis, the respondents answered almost in a similar way. For instance, experienced teacher A stated that she follows a simple model of lesson planning which she learnt during her pre-service teacher training. She was a science teacher and was teaching science for the last six years. She further added that her model consists of specific behavioral learning objectives, list of teaching materials, major content, and methodology used to teach that particular lesson. She further stated that when she started teaching as a fresh teacher, she used to develop too much detailed lesson plan with all nitty-gritty. For example, "I used to give very details from how teacher enters the class to what teacher says while leaving the class".

On the other hand, the experience teacher B who was an English teacher uses different format. Teacher B stated that "as I am a language teacher, therefore I focus on four skills; reading, writing, listening, and speaking. I start my lesson with learning outcomes, list of teaching aids, language skill focused, and warm up activity, introduction of the lesson, presentation, practice, and evaluation". Moreover, she focuses on different language skills in different lessons; for example, sometimes she uses strategies for reading, sometimes for writing, listening, and sometime for writing strategies only.

While the novice teacher $\mathrm{C}$ stated that, "there are some basic components of lesson, if we say the constant components for example objectives of lesson planning than previous knowledge test, teachers' presentation, students' practice activities, students' evaluation questions, and homework. These are commonly used components of lesson plan". Similarly, novice teacher D uses the same components for the lesson plan. She was of the view that "I start my lesson plan with the general information about the topic, number of students, time available, and date. After mentioning the general information about the class, I state the specific objectives for the lesson. I always make sure that my objectives should be SMART (Specific, measurable, attainable, relevant, and time bound). I don't go for more than three objectives for a class of 45 minutes. Later I develop a list of teaching aids or resources I needed to teach that topic followed by teaching method and strategies I use to teach that particular lesson. I also mention students' previous knowledge test, introduction of the topic, presentation, practice, assessment, and homework". Novice teacher D further added that this model was given to her when she was getting a pre-service training of teaching. Since then she follows this model. She further stated that for the last one year she has been developing lessons regularly for every course she teaches by following the same components.

According to the participants there are different formats and models of lesson planning which can be used for any subject anytime. However, the sequence of the lesson is itself important to teach in proper way because a teacher do activities in chronological order and it is also helpful for a teacher to teach in proper way, so that the sequence is important component of lesson plan.

iv. Challenges faced by teachers while developing daily lesson plans

With regard to this question experienced teachers A and B stated that they hardly face any difficulty in planning lessons because it has been a while since they are planning. One of the challenges they face was workload in school. Both the teachers were teaching six courses on a daily basis that's why it was very hard for them to develop a written detailed lesson plan for each and every lesson. When they started their career as teachers, they used to do it but now they just develop an outline which consists of objectives, materials required, teaching method, and student's practice activities. They don't go too much into details of the lesson. Besides teaching, they have other administrative academic tasks assigned by their principal along with marking students' homework and tests. Therefore, they do not develop a detailed lesson plan for their classes.

Contrary to the experienced teachers, for novice teacher C and D, in the beginning it was so hard for them to develop SMART objectives for each and every topic. They used to develop general objectives which were not acceptable by the subject coordinator or principal. Another challenge they faced was time allocation or each component of the lesson. For example, sometimes motivational activity or introduction of the lesson took so much of the class time. Technically teachers' presentation and students practice should take a lot of time. Both the participants also mentioned that sometimes classroom management issues emerged about which they didn't even think of. Most of their time was taken by classroom management problems. Another problem about which they talked was developing teaching aids. Due to teaching workload, both the participants stated that they cannot 
develop required teaching aids such as charts, models, and activity sheets for students on regular basis. They also mentioned the budget constraints of the school as well. They don't have a photocopy machine at school; neither had a separate budget for the required stationary. They don't have well equipped science laboratories as well.

Participant $\mathrm{C}$ pointed out that sometimes she gets confused with different models of lesson plans. Whenever a teacher educator or education officer comes to the school, he/she talks about a different model which really confuses teachers. She further stated that one of the challenges she faced was how to use a textbook effectively while teaching as a teaching resource. She thought that textbook plays a very vital role in students learning even after school. During her teacher training, she was not told or taught the effective use of textbook in planning and execution of lesson. In addition to that, novice teacher D reported that giving a logical sequence to the lesson was a real challenge for her. For example, sometimes due to a classroom management problem or any other interruption, she changes the sequence of the lesson which becomes messy at times. Moreover, she also finds it challenging to think about different motivational activities relevant to the topic each time.

\section{DISCUSSION AND CONCLUSION}

This research study intended to explore the perception of experienced and novice teachers about the importance of preparing lesson plan for effective learning. The study revealed that, novice and experienced teachers both perceived lesson planning as a guideline or blue print which depicts the classroom activities of a teacher in a specified time. Both type of teachers agreed that lesson planning helps teachers to achieve their lesson objectives because it keeps them focused on a topic. It was also found that lesson planning gives confidence to teachers to stand in front of the class and teach. Moreover, it also helps teachers to create a learning environment in the class because it given opportunities to think about variety of ways to keep students busy in different activities. The literature also supports that (Jensen. 2001) "a lesson plan is a particularly helpful instrument that serve as an arrangement, direct, source, and chronological manuscript which reflects the teaching philosophy, student population, textbooks, activities, and our goal for our students" (p. 403). Similarly, Brown (2001) stated that the effective lesson plan involves thought of more than just what is going to be educated (the objective) and how it will be educated (materials, equipment, time management, activities and achieve goals.

With regard to the effect of lesson planning on students learning, the study revealed that both experienced and novice teachers highlighted the importance of lesson planning for better students learning. It is revealed that teachers who plan their lessons by keeping in mind the students' previous knowledge and competencies; they develop students from that point onwards. When teachers plan their lessons it ultimately contributes to their learning. It is evident that lesson planning is not only important for teachers but it is also important for student learning. The above findings show that there is deep similarity among the views of respondents about the perception of teachers in the effective learning of the students. While literature suggested that teachers need to provide the instructions in proper way and provide chance for the learners in proper way where they practically involve themselves in studies. According to Justman and Mais (1956), lesson plan should replicate the methods of teaching of the teachers' effort for the learners. The lesson plan is guide which provides the basic information about the management of class for each teacher and structures their daily lesson according to the provided resources for learners. The lesson planning is the technique to evaluate the performance of educators which assess the teaching methods between previous knowledge and new learning (Pinker, 2007).

It was revealed that experienced and novice teachers followed similar models for planning their lessons on daily basis, however, some teachers use more descriptive lesson plans as compared to others who just mention the outline. It was found that teachers usually follow a simple model consist of specific behavioral learning objectives, list of teaching materials, major content, and methodology used to teach that particular lesson, time for each step of the lesson, practice activities, evaluation, and homework. Spratt et al. (2005) provided a summary about the lesson planning components. Furthermore, Richard - Amato (2009) suggests a five phased structure for a lesson; opening, simulation, instruction, closure, and follow up. Likewise, McMullin, (1992) stated that lesson plan is composed of the components like Warm-up/Review, presentation, practice, and evaluation. 
With regard to the challenges faces by novice and experienced teachers while planning their daily lesson plan, it is revealed due to workload in school teachers do not plan their written lesson for every subject they teach on daily basis. Experienced teachers do not develop detail lesson plans because they think that they have enough teaching experience so they don't need to go into too much detail. On the other hand, novice teachers face difficulty in designing SMART objectives and alignment of the lesson objectives with the lesson activities. Novice teachers also face difficulty in planning motivational activities to initiate the class. Moreover, novice teachers also stated that due to workload they cannot develop effective teaching aids for every class and subject they teach on regular basis. Another confusion for novice teachers was about different models of lesson planning, some ask for detailed lesson plans on the other hand some asked for less details. It was also revealed that novice teachers also find it difficult to use textbook effectively while planning a lesson, sequence and coherence of different components, and designing activities according to the level of students. From the literature, it was evident that novice and experienced teachers both plan their lessons but the differences lie in the type of lessons they plan. According to John (2006), novice teachers focus on short term planning, more detailed lesson plans by following a strict order of lesson components. They struggle with classroom management problems, developing and managing resources, and time management. On the other hand, experienced teachers either develop an outline for their lessons or a general outline of a lesson in their mind. They make decisions on need basis and when the situation arises in the classroom.

\section{RECOMMENDATIONS}

Based on the key findings of the study, it was found that workload was an issue for both the experienced and novice teachers to design effective lesson plans. Hence, it is recommended to the concerned school administration to minimize workload of teachers. Moreover, the school administration is recommended to provide mentoring services of experienced teachers to novice teachers, so that they can address issues of novice teachers in helping them designing SMART objectives, aligning lesson objectives with lesson activities, training novice teachers in designing motivational activities, and designing effective teaching adds for each lesson. The school administration is also recommended to choose a common lesson plan structure and make it part of their school policy, so novice teachers will not be confused about lesson plan models. The school administration is recommended to train novice teachers in designing syllabus organization for yearly, monthly, and weekly bases, so that novice teachers will learn the necessary skills of effective utilization of books in alignment with the national curriculum as well.

The researchers recommend that teachers should plan lessons for each class in different styles according to need of the subject. Moreover, it is also recommended that lesson plan should be flexible to change the method if there is any need to change in lesson during class. The teacher should properly manage the time and focus on the holistic development of learners. The researchers also suggested that teacher educators serving in different teacher education institutions should educate prospective teachers or future teachers about different effective models of lesson planning so that they could implement those models in future. An updated model of lesson planning is BOPPPS model, which can be used to develop lesson plan. Teacher education institutions should also focus on alignment among different lesson planning components. It is also recommended that teacher educators during pre-service teacher training need to focus on how to manage classroom time, classroom management, students' behavioral management, and how to design teaching aids effectively and efficiently and designing motivational activities.

\section{CONCLUSION}

This study intended to explore the perceptions of novice and experienced teachers of a private school about the importance of lesson planning and its effects on students' learning. The study also explored different models used by both the categories of teachers to plan their lessons. Furthermore, the study also identified the problems faced by the teachers while designing effective lessons.

By analyzing the responses of experienced and novice teachers, it can be concluded that both novice and experienced teachers perceived lesson planning as a guideline and a blue print for them which depicts the classroom happening before hand. Through lesson planning, novice and experience teachers both achieve their lesson objectives in a specified time. Moreover, it gives them confidence 
to teach to their classes without any confusion. While planning, teachers think about the overall syllabus, its objectives, their own teaching methodology, students' previous knowledge, and the resources or teaching aids available to them. Both the teachers perceived that lesson plan helps them to organized themselves, manage their class in an effective manner, and keep their students busy during class in purposeful activities.

It can also be concluded that both the novice and experienced teachers considered lesson planning not only important for them but they regarded it important for their students' learning. Lesson plan helps them save their time and manage and organize teaching resources effectively. Both the categories of teachers perceived a positive relationship of their lesson planning with students' learning. Hence, they consider lesson plan should be developed in such a way which should provide the basic information to the teacher and students. It should contain all components of a lesson and provide the subway for student's learning.

From this study, it can be concluded that there are different formats and models of lesson planning used by both the novice and experienced teachers based on their training, and early experiences. Finally, both the novice and experienced teachers highlighted workload as the common factor in hindering effective lesson planning for each class. Both the teachers were teaching six courses on a daily basis, besides administrative responsibilities of experienced teachers. That's why it was very hard for them to develop a written detailed lesson plan for each and every lesson. Novice find it difficult to develop SMART objectives for each and every topic. Time allocation for each component of the lesson was difficult for them besides dealing with classroom management issues emerged during teaching. Moreover, developing teaching aids with heavy workload was another issue highlighted by novice teachers besides budget constraints that hinder them to photocopy teaching notes and activities for their students.

\section{REFERENCES}

Afswa, A. (2002). Analysis of lesson plan: The case of English teaching in KAFA Zone. Retrieved from http://213.55.95.56/bitstream/handle/123456789/7010/Abebe\%20Asfaw.pdf?sequence=1\&is Allowed=y

Aggarwal, J.C (1996). Principles Methods and Techniques of Teaching. New Delhi: Vikas.

Amininik, S, Amami. S, Jalalpour. S, Azodi. P. (2000). Survey of relation between lesson plan qualities with student views about Bushehr University of Medical Sciences faculty members. The Journal of national conference on medical education Tehran Iran, 2000:8

Brown, H. D. (2001). Teaching by principles: An interactive approach to language pedagogy. Englewood Cliffs, NJ: Longman

Coppola, A.J., Scricca, D.B., Conners, G.E. (2004). Supportive Corwi supervision: Becoming a teacher of teachers. CA, Thousand Corwi Oaks: press.

Callahan, J.F, and Clark, L.H (1988).Teaching in the Middle and Secondary School Planning for Competence. New York: Macmillan.

Calder head, J. (1996). Teachers: Beliefs and knowledge. In D.C. Berliner \& R. C. Calfee (Eds.), Handbook of educational psychology (p. 709 - 725). New York: Simon \& Schuster Macmillan.

Clark, C and Yinger, R. (1998). Teacher Planning in J. Calderhead (ed.) Exploring Teachers' Thinking. London: CasselleEducational (ed.) Exploring Teachers' Thinking. London: Casselle.

Cicek, V., \& Tok, H. (2014). Effective Use of Lesson Plans to Enhance Education in U.S. and Turkish Kindergarten thru 12th Grade Public School System: A Comparative Study. International Journal of Teaching and Education, 2(2), 10-20.

Cummings, C. (2000). Winning Strategies of Classroom Management (p. 02). USA: ASCD publication.

Dale, E. (1954). Audiovisual methods in teaching. New York: Dryden press.

Davies, D., \& Rogers, M. (2000). Pre-service Primary Teachers' Planning for Science and Technology Activities: influences and constraints. Research in Science \&Technological Education, $18(2), 215-226$. 
Perceptions of Experienced and Novice Teachers about the Importance of lesson planning...

Dean, J. (1996). Beginning Teaching in the Secondary School Buckingham, Philadelphia: Open University Press.

Farrell, T. S. C. (2002) Lesson Planning in Methodology in Language Teaching: An Anthology of Current Practice, Jack C. Richards (Editor), Willy A. Renandya (Editor) New York: Cambridge University Press.

Gieve, S. \& Miller, I. (2006). Understanding the language Classroom. New York: Palgrave Macmillan.

Harmer, J. (2006). The Practice of English Language Teaching (3rd ed., pp.8-10 308). Malaysia: Pearson education limited.

Haynes, A. (2010). The Complete Guide to Lesson Planning and Preparation. London: Continuum.

Hannon FB. (2000). A national medical education needs assessment of International the development of an intern education and training program.

Med. Educ. (2000). Education. International Journal of Foreign, 34(4), 275-84

Jensen, L. (2001). Planning lessons. In M. Murcia, Teaching English as a second or foreign language (pp. 403 - 413). Boston: Heinle \& Heinle Publishers.

John, P.D. (1993). Lesson Planning for Teachers. London: Casselle Educational Limited.

John, P. D. (1991a). Course, curricular, and classroom influences on the development of student teachers' lesson planning perspectives. Teaching and Teacher Education, 7(4), 359-372.

John, P. D. (2006). Lesson planning and the student teacher: re-thinking the Dominant model. Journal of Curriculum Studies, 38(4), 483 - 498.

Kizlik, B. (2008). Lesson Planning, Lesson Plan Formats and Lesson Plan ideas. Retrieved May 8, 2008 from http://www.adprima.com/lesson.htm.

Kyriacou, C. (2007). Essential teaching skills (3rd ed). China: Nelson Thornes.

Koszalka, T. A., Breman, J., Moore, M.K. (1999). Sharing Lesson Plans over the World Wide Web: Important Components. Education and Information Technologies, 4 (2), 143-151.

Lang, H.R. et al. (1994). Teaching: Strategies and Methods for Student Centered Instruction. Canada: Harcourt Grace \& Company.

Mahon, A. (2011). Lesson Plan to train like you fly: A flight instructor's reference for scenario based training (p. 04). Washington: Aviation supplies and academic. INC.

Marzano, R. J.; Marzano, J. S.; Pickering, D. J. (2003) Classroom Management That Works: Research-Based Strategies for Every Teacher, Association for Supervision \& Curriculum Development Publications.

McCutcheon, G., \& Milner, H. R. (2002). A contemporary study of teacher planning in a high school English class. Teaching and teaching: theory and practice, 8(1). 81-94.

Moradana, A., \&, Pourasadollahb, R.(2014). Teachers' Thinking about Their Teaching: A Critical Study on Iranian TEFL Teachers. Procedia Journal of Social and Behavioral Sciences 98 (2014) 1194 - 1203. Semnan -, Iran. Available online at www.sciencedirect.com, 81-94.

Nasri, A. J., \& Heideri, M. (2014). The important role of lesson plan on educational achievement of Iranian EFL teachers' attitudes. International Journal of Foreign Language Teaching and Research, 2(5), Ornstein, A.C. (1997). How teachers plan lessons in Koszalka et al.

(1999). Sharing Lesson Plans over the World Wide Web: Important Components. Education and Information Technologies, 4(2), 143-151.

Preagent, R. (1990) Preparation d'un course (Charting your Course: How to Prepare to Teach More effectively). Montreal; EÂ ditions de l'EÂcolePoly technique de Montre Âal.

Piaget, J. (1976). The child and reality: Problems of genetic Psychology. New York: Penguin Book.

Peterson, P. L., Marx, R. W., \& Clark, C. M. (1978). Teacher planning, teacher behavior, and student achievement. American Educational Research Journal, 15(3), 417-432.

Richards, J., \& Bohlke, D. (2011). Creating effective language lessons (p .03, 302). Cambridge: Cambridge University Press.

Scrivener, J. (2013). Classroom Management Techniques (pp. 1-2). United Kingdom: Cambridge University Press.

Sarosedy, J., T., Poor, Z., \& Vadnay, M. (2006). Applied linguistic: for BA student in English, 44, 5.

Shen. J et al. (2007a). Lesson Planning: A Practice of Professional Responsibility and Development. Educational Horizons, 85(4), 248-258.

Singh, Y. (2007). Teaching of English. India: APA Publishing Corporation. 
Tyler, R. W. (1949) Basic Principles of Curriculum and Instruction (Chicago: University of Chicago Press).

Wong, H. K.; Wong, R. T. (2009). The First Days of School: How to Be an Effective Teacher, Harry $K$. Wong Publications, 12(81), 87-100.

Yildırım, A. (2003). Instructional planning in a centralized school system Lessons of a study among primary school teachers in Turkey, International Review of Education, 49(5), 523-543. 